\title{
System as Integration Concept In Industrial Engineering and Islam
}

\author{
Roikhan Mochamad Aziz ${ }^{1}$, Refti Muniva Kiendra ${ }^{2}$ \\ \{roikhan.ma@uinjkt.ac.id ${ }^{1}$,reftikiendra27@gmail.com ${ }^{2}$ \} \\ Universitas Islam Negeri Syarif Hidayatullah, Jakarta, Indonesia ${ }^{1}$, \\ Institut Teknologi Bandung, Bandung, Indonesia ${ }^{2}$
}

\begin{abstract}
The aim of this research is to analyze the methodology of a system for Industrial Engineering and Islam. This research uses the qualitative method and comparative method approach. The data was obtained by literature review and desk study from journals, books, and some authority websites. The results show that between Industrial and Islamic Engineering, the system has the same methodology. The difference is only in the subject of the variable and its flow.
\end{abstract}

Keywords: Industrial Engineering, Value Systems, Final Ways, Socio-Political History, Research Methodology

\section{Introduction}

Today's science continues to develop in extraordinary ways along with the progress of human thinking and knowledge. The development of science has entered almost all fields of life in modern society. Only a small number of societies that are completely untouched by the products of scientists. However, various benefits are felt by the community with advances in science and technology. But the industry also still has a negative impact on society.

The history of industrial engineering cannot be separated from the industrial revolution in England which took place at the end of the 18th century, especially on year 1769-1800. At that time, James Watt invented a steam engine which then caused a very fundamental change in the production sector, namely from a production system that is a home industry to a fabrication industrial system (factory system). As a result of this change, there is a replacement of human labor with machines which rapidly increases plant capacity. Increased factory capacity has resulted in market expansion to sell products in line with the expansion of the colony, rapid growth in the industrial sector, and accumulation of resources.

According to The American Institute of Industrial Engineers (AIIE), the earliest definition of industrial engineering was issued in 1948 as follows:

"Industrial Engineering is concerned with the design, improvement, and installation of integrated systems of men, materials, and machines. It draws upon specialized knowledge and skills in the mathematical, physical, and social sciences together with the principles and methods of engineering analysis and design to specify, predict, and evaluate the results to be obtained from such a system."

In accordance with its development, AIIE changed its name to The Institue of Industrial Engineers (IIE) and the definition of Industrial engineering also changed in 1984 to become as follows: 
"Industrial Engineering is concerned with the design, improvement, and installation of integrated systems of people, materials, information, equipment, and energy, it draws upon specialized knowledge and skills in the mathematical, physical, and social sciences together with the principle and methods of engineering analysis and design to specify, predict, and evaluate the results to be obtained from such a system.”[2]

From this definition, it is staed that Industrial Engineering has a fixed object of study, known as the integral system although the components have changed following the development of their environment. This shows that the objects and scope of Industrial Engineering are dynamic, which also results in the need to always update the supporting scientific fields in accordance with the changes in the environment, which even if seen from the basic principles of science, it still does not experience changes.

Industry is one of the economic resources which is currently an inseparable part of economic life. In accordance with changing times, the industry has also changed, from the very simple way to the most sophisticated way. As a country with the largest Muslim population in the world, Indonesia must integrate Islamic values in Industrial Engineering. The development of Industrial Engineering is very influential on the ways of people's lives today, where almost all aspects of life are strongly influenced by the development of Industrial Engineering.

This is described as specific knowledge and skills in mathematics, physics, chemistry, and biology and social science along with the principles and methods of analysis and design techniques to specialize, predict, and evaluate the results to be achieved from a system. Industrial engineering is an integral system consisting of people, materials, information, equipment, and energy. Industrial Engineering is the basic scientific in multidisciplinary industrial engineering, because industrial engineering is not only based on mathematics, chemistry, biology, and physics, but also social science and management.

Industrial engineering has been integrated in human life with evidence of the increasing number of people highly dependent on the industry sector. Human behavior requires products from industries that cannot be separated from life such as the electronics industry, machinery industry, metal (iron) industry, food and beverage industry. Basically, the development of Industrial Engineering is very beneficial for human life to facilitate human work in daily life, but the magnitude of the benefits of industry has a negative influence in all fields and even affects morals (akhlaq), mindset / belief (aqeedah), and way of life human (sharia).

Industrial Engineering as a study discipline cannot be separated from other disciplines. The concept of industrial engineering that aims to obtain work efficiency in all fields of work clearly requires assistance from other disciplines. The application of the industrial engineering discipline itself extends to all areas of life and is not only applied specifically to industry, but also to all operations in government, commerce, and services.

Mechanical engineering is a discipline that is the forerunner to the establishment of Industrial Engineering which is closely related to other sciences such as mechanics, psychology, computer science, management, statistics, operational research and social sciences. The integration of the fields of science that are closely related to systems engineering is known by the fields of industrial science and systems engineering. Industrial and systems engineering will design systems at two levels, known as the first level of the system level of human activity and emphasized in the physical workplace where human activity occurs. At the second level, it is called a management supervision system and emphasizes procedures, planning, measurement, supervision for all activities in the organization.

Industrial engineering discipline is intended to solve problems in the industrial sector (all business organizations include the production of goods / manufacturing and services) and non- 
industry. In short, the industrial engineering approach is suitable for decision making in management analysis by looking at problems as part of an integral system (the concept of a de-coupling system).

Seeing this problem, there is a reminder of religion or belief that serves as a foundation on which there are already rules and restrictions in running life. Islam is a religion that pays attention to all aspects of life and everything has been arranged in accordance with the command of Allah.

QA. Al-Kahfi [18] verses 96

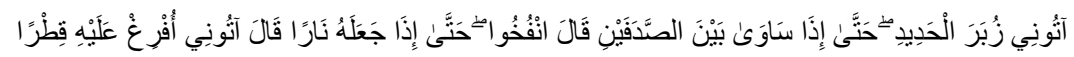

It means "give me pieces of iron" Until when the iron has been leveled with the two (peaks) of the mountain, said Dhulqarnain: Blow (the fire) ". Until when the iron has become (red like) fire, he too says: "Give me the boil (which boils) so that I pour it on the hot iron."

From this verse shown in the Qur'an, the process of raw materials is described which can be processed into goods that are more than their original function. In addition, there are a number of verses that implicitly refer to the industrial management of these goods. The main thing is how Islam shows things that are now considered more important than simple.

Considering that Islam that lives in the awareness of every Muslim includes or encompasses all aspects of life without exception, then trying to examine relations with Industrial Engineering is inevitable. Because the industrial life of a Muslim technician is one aspect of his life that may not be excluded from whole person.

\section{Literature review}

An understanding of Islam as accurately as possible will be explored based on the AlQuran 'Karim and the translation of the publication of the Ministry of Religion of the Republic of Indonesia in collaboration with the Government of Saudi Arabia.

\subsection{The nature of Islam}

Islam is the only one that means 'ad-diin' with the meaning of life guidelines for human beings that are recognized, blessed, blessed, and established by the Creator and Preserver and Ruler of The Universe, that is God Almighty. Quran Surah Ali Imran (3): 85.

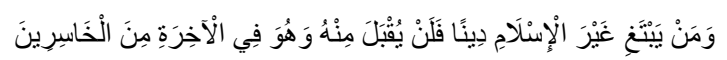

"Whoever seeks a religion other than Islam, will never be accepted from it, and he is in the afterlife including those who lose".

This means that a believer submit themselves with all their heart and body to God, while an unbeliever submit himself to God by force, because they are under submission, conquest, and extraordinary strength which he cannot avoid and reject.

Islam as Divinity does not only mean religion that has a narrow connotation, which is a ritual of teaching God, but rather connotes as a guide to life that is absolute, comprehensive, covering, covering $100 \%$ aspects of human life without the slightest exception. (see QS.AlBaqarah (2): 208) 
Technically speaking, Islam is a guideline for all living systems, economic systems, politics, arts and culture, science and technology, law, education, society, defense, security, international relations, and all living systems or sub-systems. Islam is a complete civilization and human happiness is not limited to the world but continues into the afterlife.

\subsection{Islam is a time of life}

The dimension of time is an absolute element that surrounds human life. There are the dimensions of space and time that are destined for universe by creator. Interesting and very important what is emphasized in QS. Al-Ashr (103): 1. "For the sake of time". The scholars agreed to interpret this verse as: pay attention to time!

Imagination of life only a few seconds, until it turns out that human must make up for sanctions into the world with twice the wealth of the entire earth which is filled with the added value of the most sophisticated technology, but it still will not be accepted by the ransom: "Indeed, those who disbelieve even though they have what who are on this earth fully and have more to redeem themselves with it from Judgment Day, surely the ransom will not be realized by them, and they will receive a painful punishment." (QS. Al-Maidah (5): 36). This is what is meant by Islam as the time of life.

\subsection{Islam is a value system}

Humans certainly and truly assess everything in their lives [1]. Symptoms of a simple assessment for example is when he is hungry, then he will judge the act of eating well. From this it can be understood that assessment comes from interest. In accordance with the nature of his own creation, the most obvious and explicit interest is physiological interest, such as eating, drinking, healthy, growth, and so on.

Everything that is in line with the fulfillment of these interests must be judged as good or bad. And vice versa, the opposite will be judged not bad or not good. Humans also have psychological interests such as the love of wealth, the throne / position, and the opposite sex. Then a good all-round assessment will appear if everything is in accordance with the fulfillment of this love.

It turns out that humans are not separated from spiritual interests. The proof is that even if humans do not worship the original God, humans still need interaction with various forms of abstraction, both tangible and intangible material.

\subsection{Islam is a way of thinking}

The thought process in Industrial Engineering seems clear that everything starts from the goal then goes backwards. Identity of purpose with interest. Interest will have implications for valuation. So if someone adopts the Islamic value system automatically the way of thinking is also Islamic.

A Muslim who understands and fully understands their Islamic self will naturally think in an Islamic way. This means that because humans study Islam as deeply and broadly as possible it has certainly influenced the way of thinking.

The differentiation between ways of thinking in industrial and Islamic engineering is about backward loops. In industrial engineering, the reverse loop has been defined as a feeadback flow, but in Islam the reverse loop will be converted to vairbale from feedback. Summary of feedback in the enginerring industry is flow, and Islam is variable. 


\subsection{The Nature of industrial engineering}

So far in the study of Industrial Engineering taught at universities in Indonesia. The term engineering is often associated with technology or applied science. One of the engineering study programs is industrial engineering. If interpreted in words, industrial engineering is the science of engineering or reconstructing industry.

According to IIE (Institute of Industrial Engineering), industrial engineering is concerned with the design, improvement and installation of integrated systems of people, materials, information, equipment and energy. It utilizes specific knowledge and skills in mathematical, physical, and social sciences along with the principles and methods of analysis and design techniques to determine, predict, and evaluate the results to be obtained from such a system $[2]$.

While one perspective that has never been raised is the history of Industrial Engineering in terms of socio-politics, the cultural environment that gave birth to it and which continues to surround it until the 21 st century now.

Research must be carried out once more, related to whether the dynamics of the two are not interrupted while the people who are actors or objects or only the affected audience are the same and when viewed in different angles the question arises whether Industrial Engineering was born. from history like this it is impossible to do and the beliefs, value systems and sociopolitical thinking that surrounds it or not.

\section{Methodology}

In studying industrial science, Lean Manufacturing, as a philosophy developed by Toyota in the Toyota Production System. Lean manufacturing in the Toyota Production System focuses on reducing waste, often known as Seven Waste. Seven Waste is a type of waste that occurs in a manufacturing or service process, which is called Transportation, Inventory, Movement, Waiting, Excessive Process, Overproduction, Damaged Goods. From an Islamic perspective, this waste is often called the word mubadzir. In Islam it also teaches people not to live in vain lives like the word of God in the Qur'an.

This waste minimization is one of the studies of industrial engineering students. Some programs that support this process are Factory Layout Design (PTLP), Management Accounting, Production Planning and Inventory Control, Operations Research, Material Selection and Manufacturing Process, Feasibility Study, Supply Chain Management, Lean Manufacturing and others.

Islam has principles and also with industrial engineering experience has several principles. Although these two different things become one does not deny that one of these values can eliminate the other value or say its value is more influential. Therefore, humans as caliphs on earth must always be able to balance the two things that are the basis of the values of life, Islam so that humans do not cross the limits set by God in carrying out their duties or doing in the engineering industry. 


\section{Analysis}

The nature of Islam and the nature of industrial engineering are two data that will be analyzed in this section. What is clear from both data is an error in the human element. Islam clearly talks about how humans should or should and must live their lives. While industrial engineering also makes humans part of the system being studied. But the definition of Industrial Engineering emphasizes the position of humans as subjects rather than subjects.

Islam is more proportional by stating that humans can act as subjects or objects or both at the same time. If we look at capitalist history, it will become clear why humans have more objects in the system studied by industrial engineering. This happens because industrial engineering is in the interests of the owner of the company or industry. Not for the sake of workers in the industry, or for the sake of both parties.

The industrial system belongs to the entrepreneur and must work in the interests of the entrepreneur. For this purpose, it can be concluded that humanity is what connects Islam with Industrial Engineering. Understanding the value system and way of thinking only exists in humans, not in raw materials, equipment, or energy which are the three elements other than humans in the system studied by industrial engineering. So the relationship between Islam and industrial engineering must be sought on two parameters in humans, namely the value system and way of thinking.

In the socio-political-cultural history surrounding the birth of industrial engineering, it can be assumed that this science contains a value system of secularism, empiricism, materialism, humanism, and its derivatives, known as capitalism. Further and more specific research is needed, for example exploring value systems in Financial Analysis, Factory Layout, or other subjects.

From the analysis of the data it can be understood that industrial techniques are partly compatible and the rest are incompatible with Islam. This compatibility or not specifically refers to the value system (way of thinking) it contains. So at first glance isolating industrial techniques is easy and simple, that is, only replacing value systems that are not in accordance with Islam but industrial engineering is very dynamic and continues to grow and develop rapidly in the world with all its effects. This will continue to be taught in lectures everywhere, including at the Syarif Hidayatullah State Islamic University Jakarta which bears the Islamic label. The latest textbooks, the latest research journals continue to emerge from day to day, directly interacting with the real world from their application. It is sufficient to state that certain value systems are replaced by Islamic value systems that seem inadequate. More strategic steps are needed. There are several strategies:

1. Continue to study Industrial Engineering from all over the world so that we never miss in following its development, both from books, journals, magazines, seminars, internet, and others.

2. We are also very obliged to learn about Islam independently and learn from experts, according to the example of the Prophet Muhammad who studied Islam

3. Every book / journal / paper / seminar on Industrial Engineering studied by scholars in step 1 dares to comment, we include opinions based on Islam that absorb through step 2. And it would be better if formalized in writing and delivered in lectures for students.

4. Bringing the topic of Islamic Industrial Engineering Research Methodology both for students in their final project / thesis preparation and dosage in their research.

5. Dare to offer Islamic Industrial Engineering to the industry to be applied to get feedback which in turn will further enhance the concept of Islamic Industrial Engineering.

6. Start writing the result textbook from steps 1-5. 
7. Back to step 1.

However, in general, some industrial technical concepts or concepts that are very used such as the concept of interest in technical economics can be identified, there is no concept of human spiritualism in the industrial system at all, humans tend to be considered only as physical and psychological objects - materialistic., not or without psychological-spiritualistic. The general review shows that industrial engineering is incompatible with Islam.

But some concepts such as efficiency and should not be wasteful in deploying resources, tidiness, tight layout, ergonomic work movements to avoid work accidents, quality control with maximum accuracy (without defects) overall financial administration, appreciation and fair sanctions on labor work based on clear and open steps, and systemic, non-partial resource management, in accordance with Islam.

Industrial and Islamic engineering have the same basic concept in the flow of integration, known as systems. Industrial Engineering holds the concept of the system as a workflow in products and services. There are two main variables to indicate the flow of products and services, there are inputs and outputs. And the differentiation of Industrial Engineering in these input and output variables, there is one flow as feedback to bridge from output to input.

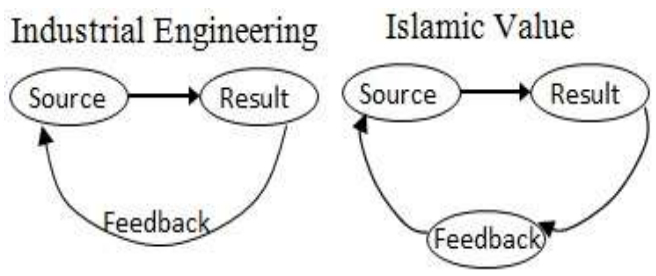

Fig. 1. Diagram industrial engineering and Islam. (Source: Analysis 2019)

In Islam, the concept of the system is the same as Industrial Engineering for workflows, there are inputs and outputs as variables. But in Islam, feedback is not used as a flow but variable. So there are three variables in Islam for the system, there are inputs, outputs, and feedback.

There are additional line and arrow in Islam, because of the feedback converted to variable.

Table 1. Differentiation of industrial engieering and Islam.

\begin{tabular}{lcc}
\hline \multicolumn{1}{c}{ Concept } & Industrial Engineering & Islam \\
\hline System & System & System \\
Variables & 2 & 3 \\
& Input & Input \\
Matter & Ouput & Output \\
& Flow & Feedback \\
Feedback & & Variable \\
Source: Analysis, 2019 & &
\end{tabular}

The system concept in Industrial Engineering is also used in Islamic values. This means that integration in Industrial Engineering to combine several different study programs to become multidisciplinary among physics, chemistry, mathematics, and biology can be worked into the Islamic system. The system in Islam can integrate several different scientific 
disciplines from science, technology, and social, along with religious studies such as Sharia, Tarbiyah, Usuluddin, Adab, and Dirosat Islamiyah.

Islam has a root word of 3 letters: $\mathrm{s}, 1, \mathrm{~m}$ or synlammim. These 3 letters can be tapped into 3 variables in the system, namely: $\mathrm{s}$ for output, 1 for input, and $\mathrm{m}$ for feddback. [3] explains that $\mathrm{s}, 1, \mathrm{~m}$ have human meaning (s, output) created by God (l, input) for worship (m, feedback).

The importance of Islam is worship or feedback, it is very argumentative that feedback must be formed as a variable, whereas Industrial Engineering has feedback as a flow only.

\section{Conclusions}

The methodology of a system in industrial engineering has the differentiation to separate input and output variables from feedback, where the variable is only input and output but feedback is not a variable but only as a flow. In Islam, a system has 3 (three) variables, namely input, output, and feedback. Systems in industrial engineering do not have intangible variables but western scholars place these intangible variables combined with one of the variables in the output and the point to flow from output to input as feedback but not as a variable.

Islam has a digital history to have 3 (three) variables in 1 (one) system such as language structure, but industrial engineering methodology has no reference to claim that in one system consisting of three variables, the system formula in industrial engineering is one. the system has two variables.

The recommendation for further research is to study the relationship between system methodology and language structure and other knowledge materials about parts of creation.

\section{References}

[1] Ali Abdul Halim Mahmud. (2005). Devices for the Muslim Brotherhood Tarbi , Eighth Edition, Era Intermedia, Jakarta.

[2] Aries, RS, ad Newton, RD (1955). " Chemical Engineering Cst Estimation”, McGraw-Hill Book Co., Inc., New York

[3] Aziz, Roikhan Mochamad. (2016). Islam Dan Pengetahuan. Salemba Diniyah, Jakarta. 